\title{
Physicochemical, enzymatic and molecular characterisation of the storage protein of aerial tuber, Dioscorea bulbifera Linn.
}

\author{
Olukemi Adetutu Osukoya ${ }^{1}$ and Adenike Kuku
}

\begin{abstract}
Background: The storage protein of the aerial tuber of Dioscorea bulbifera was purified and its physicochemical, enzymatic and molecular properties determined with a view to comparing its functionality and genetic relatedness with other storage proteins.

Results: The purified protein had molecular weight of $21 \mathrm{kDa}$. The protein showed carbonic anhydrase, trypsin inhibitory, dehydroascorbate reductase and monodehydroascorbate reductase activities. Amplifications with polymerase chain reactions resulted in the detection of two genes encoding the storage protein. The deduced amino acid sequence of the shorter and larger genes had homologies with the storage proteins of members of the Dioscorea family.

Conclusion: The study concluded that the storage protein of the aerial tuber of D. bulbifera had similar properties with those of other Dioscorea species and may be suitable for development as functional food.
\end{abstract}

Keywords: Aerial potato, Aerial yam, Bulb, Dioscorin, Storage protein, Protein purification

\section{Introduction}

Yam, a dioecious plant belonging to the Dioscorea genus, is an important staple crop in many areas of the tropics and sub-tropics [1]. There are 8 genera and 880 species of yam plant. They produce edible tubers, bulbils, corms or rhizomes [2] that are basically made up of carbohydrates and are important sources of proteins and micronutrients [3]. Yam tubers are widely utilized as food due to their compositions [4]. Yam tubers also contain functional components such as mucin, dioscin, diosgenin, allantoin, choline and polyphenol oxidases [5] and, in addition, minerals and vitamins such as calcium, zinc, phosphorus, copper, iron, sodium, potassium, $\beta$-carotene, thiamine, riboflavin and niacin [6]. About $80 \%$ of the proteins in yam are storage proteins [7], which are usually affected by

\footnotetext{
* Correspondence: akuku@oauife.edu.ng; adenikekuku@yahoo.com ${ }^{2}$ Department of Biochemistry and Molecular Biology, Obafemi Awolowo University, lle-lfe, Nigeria

Full list of author information is available at the end of the article
}

factors such as cultural practices, climate, soil fertility, maturity at harvest and length of storage time [8].

Plants accumulate storage substances such as starch, lipids and proteins in certain phases of development. The major role of storage proteins is to act as stores of nitrogen, sulphur and carbon, which are accumulated in both vegetative and reproductive tissues. Thus, they serve as a reservoir for later stages of plant development $[9,10]$. Storage proteins provide nutrients to support the growth of new plants as seedlings (from seeds) or shoots (from tubers). They are localized in specific organs, cell types and subcellular compartments in discrete deposits (protein bodies) where they facilitate high-level accumulation without any adverse effects on other cellular functions. They also allow plants to survive periods of adverse conditions between growing season [11]. Plant storage proteins are grouped into two classes: seed storage proteins that accumulate to high levels in seeds during the late stages of seed development, and vegetative

\section{Springer Open}

(- The Author(s). 2020 Open Access This article is licensed under a Creative Commons Attribution 4.0 International License, which permits use, sharing, adaptation, distribution and reproduction in any medium or format, as long as you give appropriate credit to the original author(s) and the source, provide a link to the Creative Commons licence, and indicate if changes were made. The images or other third party material in this article are included in the article's Creative Commons licence, unless indicated otherwise in a credit line to the material. If material is not included in the article's Creative Commons licence and your intended use is not permitted by statutory regulation or exceeds the permitted use, you will need to obtain permission directly from the copyright holder. To view a copy of this licence, visit http://creativecommons.org/licenses/by/4.0/. 
storage proteins, which accumulate in vegetative tissues such as leaves, stems and tubers [12].

Dioscorins, yam storage proteins, isolated from different Dioscorea species have been shown to have various biological activities, which include enzymatic ( $\alpha$-carbonic anhydrase, trypsin inhibitory), antioxidant, antihypertensive and immunomodulatory activities. They are thus worth developing as healthy or functional foods. Dioscorea bulbifera belongs to the family Dioscoreaceae assigned to the order Dioscorales. It is commonly known as air potato, potato yam, air yam, or bulbil-bearing yam. It is native to Africa and Asia but widely grown and consumed in the tropics [13], the Caribbean Islands, South East Asia, South Pacific and West Indies. The uncultivated form is bitter, not edible and may be poisonous. Air potato plants produce "aerial tubers" that are attached closely to the axil. These aerial tubers (bulbils) are usually round or spherical with mostly smooth surfaces. The aerial tuber (from where the name 'air potato' is derived) serves as the main storage organ of $D$. bulbifera $[13,14]$. The aerial tubers of $D$. bulbifera are commonly consumed especially in South Eastern Nigeria and serve as a good source of calories and minerals [15]. The plant has many health benefits and is used in folk medicine as analgesic, aphrodisiac, diuretic and rejuvenative tonic. It is also used as a folk remedy to treat conjunctivitis, diarrhea and dysentery $[16,17]$. Despite all its medicinal and agricultural uses, D. bulbifera is widely characterized as an organism that outcompetes and smothers native vegetation and is usually considered as weed by farmers. It is thus paramount to investigate the properties of some of the bioactive molecules such as the major storage protein. The study aimed at isolating and purifying the storage protein from the aerial tubers of Dioscorea bulbifera, determining some of its physicochemical properties, identifying and sequencing the gene encoding the storage protein and establishing the phylogenetic relatedness with the storage proteins from other Dioscorea species.

\section{Methods}

\section{Materials}

Dioscorea bulbifera aerial tubers were obtained from a farmland in Amichi, Nnewi South Local Government of Anambra State, Nigeria. The plant was identified in the IFE Herbarium of the Department of Botany, Obafemi Awolowo University, Ile-Ife, Nigeria, where the specimen copy was deposited and voucher number IFE-14754 was given.

All chemicals and reagents used were purchased from either Sigma Chemical Co. (St. Louis, MO, USA), Pharmacia Chemicals (Uppsala, Sweden) or Bio-Rad Lab (Hercules, CA, USA).

\section{Preparation of crude extracts}

The crude extract of the aerial tubers of Dioscorea bulbifera was prepared at different $\mathrm{pH}$ and varying temperature, in order to ascertain conditions at which most of the proteins in the aerial tuber are solubilized.

Dioscorea bulbifera aerial tubers were peeled, sliced and homogenized with 4 volumes (w/v) of buffers at different $\mathrm{pH}: 0.5 \mathrm{M}$ citrate/phosphate buffer ( $\mathrm{pH} 4-6), 0.5$ $\mathrm{M}$ Tris- $\mathrm{HCl}$ buffer (pH 7 and $\mathrm{pH} 8.3$ ) and glycine- $\mathrm{NaOH}$ buffer ( $\mathrm{pH} 9$ and 10). The mixtures were stirred for $4 \mathrm{~h}$ and centrifuged at $13,500 \mathrm{rpm}$ for $30 \mathrm{~min}$ at $4{ }^{\circ} \mathrm{C}$. The supernatants collected were stored as crude extracts.

Also, approximately $100 \mathrm{~g}$ portions of yam slices were boiled in $1 \mathrm{~L}$ of water at $25,30,40,50,60,70,80,90$ and $100{ }^{\circ} \mathrm{C}$ for $10 \mathrm{~min}$. The treated aerial tubers were drained, cooled, weighed and homogenized with $50 \mathrm{mM}$ Tris- $\mathrm{HCl}(\mathrm{pH} 8.3)$ at 1:4 (w/v). The mixture was stirred for $4 \mathrm{~h}$ and centrifuged at $13,500 \mathrm{rpm}$ for $30 \mathrm{~min}$ at $4{ }^{\circ} \mathrm{C}$. The supernatants were collected as crude extracts.

Protein content of extracts was determined by Lowry method using $1 \mathrm{mg} / \mathrm{mL}$ bovine serum albumin (BSA) as standard.

\section{Purification of protein}

The crude extract obtained at $\mathrm{pH} 8.3$ and $25^{\circ} \mathrm{C}$ (which had the highest protein concentration) was used for further studies. Purification of the storage protein of Dioscorea bulbifera aerial tuber was carried out following the method of Hou et al. [18] with a little modification.

The crude extract of the aerial tuber of Dioscorea bulbifera was subjected to $70 \%$ ammonium sulphate precipitation, stirred and kept overnight at $4{ }^{\circ} \mathrm{C}$. The mixture was centrifuged at 13,500 rpm for $30 \mathrm{~min}$ and the precipitate recovered. The precipitate was dissolved in 10 volumes of $50 \mathrm{mM}$ Tris- $\mathrm{HCl}$ buffer, $\mathrm{pH} 8.3$ and dialyzed exhaustively against distilled water.

\section{lon-exchange chromatography on DEAE Sephadex A-25}

The dialyzed protein solution $(7.5 \mathrm{mg} / \mathrm{mL} ; 2.5 \mathrm{~mL})$ was loaded on DEAE Sephadex (A-25) ion exchange column $(1.5 \times 20 \mathrm{~cm})$ previously equilibrated with $50 \mathrm{mM}$ Tris$\mathrm{HCl}$ buffer, $\mathrm{pH}$ 8.3. Unadsorbed proteins were eluted

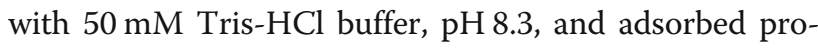
teins were eluted stepwise with $150 \mathrm{mM} \mathrm{NaCl}$ in $50 \mathrm{mM}$

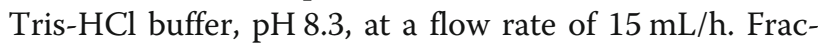
tions of $5 \mathrm{~mL}$ each were collected, and elution was monitored at $280 \mathrm{~nm}$. The adsorbed protein fractions, which correspond to the major storage protein of the aerial tuber of D. bulbifera, were pooled and concentrated.

\section{Gel filtration on Sephadex G-75}

Adsorbed protein sample $(1.5 \mathrm{mg} / \mathrm{mL} ; 5 \mathrm{~mL})$ obtained from ion-exchange chromatography was further purified by gel filtration on Sephadex G-75 column $(1.5 \times 40 \mathrm{~cm})$ 
previously equilibrated with $50 \mathrm{mM}$ Tris- $\mathrm{HCl}$ buffer, $\mathrm{pH}$ 8.3. The column was eluted with $100 \mathrm{mM}$ Tris- $\mathrm{HCl}$ buffer (pH 7.9) containing $100 \mathrm{mM} \mathrm{NaCl}$ at a flow rate of $27 \mathrm{~mL} / \mathrm{h}$. Fractions of $3.6 \mathrm{~mL}$ each were collected. The purified protein was collected, concentrated and stored at $-20^{\circ} \mathrm{C}$ for further use. Protein concentration was determined after each purification step.

\section{Non-SDS polyacrylamide gel electrophoresis}

The protein samples were subjected to polyacrylamide gel electrophoresis in the absence of sodium dodecyl sulphate (SDS) according to the modified method of Shiu et al. [19] to monitor the purity of the protein obtained after each purification step. Electrophoresis was performed on a $10 \%$ discontinuous gel system under non-denaturing conditions and stained with Coomassie Brilliant Blue.

\section{Determination of molecular weight}

The native molecular weight of the protein was determined by gel filtration on a Bio gel P-200 column $(1.5 \times$ $63 \mathrm{~cm})$ using the following protein markers: lysozyme $(\mathrm{Mr}$ 14,000), $\alpha$-chymotrypsinogen A (Mr 25,000), egg ovalbumin ( $\mathrm{Mr} 45,000)$ and bovine serum albumin ( $\mathrm{Mr} 66,000)$. Each protein $(5 \mathrm{~mL})$ was applied on the column and run separately using $10 \mathrm{mM}$ phosphate buffer $\mathrm{pH} 7.0$ as eluant at a flow rate of $10 \mathrm{~mL} / \mathrm{h}$. Fractions of $5 \mathrm{~mL}$ were collected, and the elution was monitored at $280 \mathrm{~nm}$. The void volume $\left(V_{\mathrm{o}}\right)$ of the column was determined using Blue dextran (elution monitored at $620 \mathrm{~nm}$ ).

The purified storage protein was subjected to SDSpolyacrylamide gel electrophoresis for subunit molecular weight determination following the modified method of Shiu et al. [19] using the following protein markers: ovalbumin (Mr 45,000), carbonic anhydrase (Mr 29,000), trypsinogen (Mr 24,000), trypsin inhibitor (Mr 20,000) and $\alpha$-lactalbumin (Mr 14,200).

\section{Detection of protein-bound carbohydrate}

The presence of covalently-bound carbohydrate in the storage protein was investigated by staining the gels with periodic acid-Schiff's reagent (PAS) after electrophoresis, as described in the Pharmacia Manual of Laboratory Techniques, revised edition. The protein sample was subjected to electrophoresis under non-denaturing conditions using phosphate-buffered system. After electrophoresis, the gel was fixed in $7.5 \%$ acetic acid at room temperature for $1 \mathrm{~h}$. The fixed gel was transferred into a beaker containing $0.2 \%$ aqueous periodic acid and kept at $4{ }^{\circ} \mathrm{C}$ for $45 \mathrm{~min}$. Afterwards, the gel was removed and transferred into a beaker containing Schiff's reagent, kept at $4{ }^{\circ} \mathrm{C}$ for $45 \mathrm{~min}$. The gel was destained in $10 \%$ acetic acid. Glycoprotein band (if present) will stain purplish red.

\section{Amino acid composition of the protein}

The storage protein was subjected to amino acid content analysis using methods described by Ekeanyanwu [20]. The sample was hydrolysed, evaporated in a rotary evaporator and loaded into the Technicon Sequential MultiSample Amino Acid Analyzer (TSM).

\section{Enzymatic activities of storage protein of Dioscorea bulbifera \\ Determination of carbonic anhydrase activity}

Carbonic anhydrase activity of the protein was measured by hydrolysis of 4-nitrophenyl acetate resulting in an increase of absorbance at $348 \mathrm{~nm}$ [21]. The activity of the tuber storage protein was compared with that of carbonic anhydrase from bovine erythrocytes. The reaction mixture contained $0.3 \mathrm{~mL}$ of freshly prepared $3 \mathrm{mM} \mathrm{4-}$ nitrophenyl acetate in aqueous $3 \%$ acetone and $0.7 \mathrm{~mL}$ of $15 \mathrm{mM}$ Tris sulphate buffer, pH 7.6. Exactly $10 \mu \mathrm{L}$ purified protein solution $(1 \mathrm{mg} / \mathrm{mL})$ was added, and the catalyzed reaction was monitored by measuring the increase in absorbance at $348 \mathrm{~nm}$ for $5 \mathrm{~min}$.

\section{Determination of dehydroascorbate reductase activity}

Dehydroascorbate (DHA) reductase activity of the protein was carried out according to the method of Hou et al. [18]. In this reaction, $10 \mathrm{mg}$ of DHA was dissolved in $5 \mathrm{~mL}$ of $100 \mathrm{mM}$ phosphate buffer of different $\mathrm{pH}$ values ( $\mathrm{pH} 6.0,6.5$ and 7.0). The reaction was carried out at $30{ }^{\circ} \mathrm{C} ; 100 \mu \mathrm{L}$ purified protein solution $(1 \mathrm{mg} / \mathrm{mL})$ was added to $0.9 \mathrm{~mL}$ DHA solution with or without 4 $\mathrm{mM}$ glutathione. Increase in absorbance at $265 \mathrm{~nm}$ was recorded for $5 \mathrm{~min}$. Non-enzymatic reduction of DHA in phosphate buffer was measured in a separate cuvette.

\section{Determination of monodehydroascorbate reductase activity} Monodehydroascorbate (MDA) reductase activity of the protein was assayed according to the method described by Hou et al. [18] by monitoring the decrease in absorbance at $340 \mathrm{~nm}$ due to NADH oxidation. MDA free radicals were generated by ascorbate oxidase in the assay system. The reaction mixture contained $50 \mathrm{mM}$ phosphate buffer (pH 6.0, 6.5 and 7.0); $0.33 \mathrm{mM} \mathrm{NADH;} 3$ $\mathrm{mM}$ ascorbate, ascorbate oxidase $(0.9 \mathrm{U})$; and $200 \mu \mathrm{L}$ purified protein solution ( $200 \mu \mathrm{g}$ protein) in a final volume of $1 \mathrm{~mL}$. Distilled water was used to replace protein solution in blank solutions. One unit of MDA reductase is defined as the amount of protein required to oxidize $1 \mu \mathrm{mol}$ of NADH per min.

\section{Determination of trypsin inhibitory activity}

Trypsin inhibitory activity of the protein was determined according to the method of Xue et al. [22] by monitoring the inhibition of trypsin-catalyzed hydrolysis of $\mathrm{N}$-benzoyl-L-arginine-4-nitroanilide (substrate) in $0.1 \mathrm{M}$ Tris- 
$\mathrm{HCl}$ buffer (pH 8.2). Different concentrations of the protein were pre-incubated with $20 \mu \mathrm{M}$ trypsin at room temperature for $15 \mathrm{~min}$. The substrate $(100 \mu \mathrm{g} / \mathrm{mL})$ was added to give a final volume of $1 \mathrm{~mL}$ for an additional $20 \mathrm{~min}$. The absorbance at $405 \mathrm{~nm}$ was measured. The inhibitory activity is calculated as the percentage decrease in substrate hydrolysis rate, which is directly proportional to increase in absorbance at $405 \mathrm{~nm}$. The result was expressed as micrograms of trypsin inhibited.

\section{Molecular characterization of the storage protein of Dioscorea bulbifera \\ Genomic DNA extraction}

The aerial tuber was peeled, cut into bits and ground into fine powder with a mortar and pestle under liquid nitrogen. Genomic DNA was extracted using QIAGEN DNeasy Plant Mini Kit. DNA concentrations were determined with a Nanodrop spectrophotometer (Beckman Coulter) and adjusted to $25 \mathrm{ng} / \mu \mathrm{L}$ for PCR amplification.

\section{Primer design for polymerase chain reaction}

Sequences of some Dioscorin genes from various Dioscorea sp. were obtained from NCBI nucleotide database (http:// www.ncbi.nlm.nih.gov/nuccore). These sequences were inserted into the input window of the web-based polyacrylamide chain reaction (PCR) primer designing program, Primer3 (https://primer3plus.com/cgi-bin/dev/primer3plus. cgi). The primer minimum and maximum sizes were set to 100 and 900 nucleotides, respectively. The DNA was subjected to PCR amplifications using the designed Dioscorin-specific primers $\left(5^{\prime}\right.$-CTCCTCTCCTCCCT CCTCTT-3' (forward primer) and 5'-GGGGGT ACAATGGAGAAGT G-3' (reverse primer)). The amplification was conducted in a final reaction volume of $25 \mu \mathrm{L}$ containing $5 \mu \mathrm{L}$ of DNA sample, $2.0 \mu \mathrm{L}$ $\mathrm{MgCl}_{2}, 0.2 \mu \mathrm{L} \mathrm{Taq}$ polymerase, $2.5 \mu \mathrm{L} 10 \mathrm{X}$ reaction buffer, $1 \mu \mathrm{L} \mathrm{dNTPs}, 1 \mu \mathrm{L}$ each of forward and reverse primers, $2.0 \mu \mathrm{L}$ Tween 20 and sterile deionized water in a 96-well microtiter plate and carried out in a GeneAmp PCR System 9700 (Applied Biosystems). The PCR cycles were made up of initial denaturation of DNA template at $94{ }^{\circ} \mathrm{C}$ for $3 \mathrm{~min}$, followed by 36 cycles of denaturation at $94^{\circ} \mathrm{C}$ for $1 \mathrm{~min}$, annealing at $60^{\circ} \mathrm{C}$ for $1 \mathrm{~min}$ and extension at $72^{\circ} \mathrm{C}$ for $2 \mathrm{~min}$. The final extension step was at $72^{\circ} \mathrm{C}$ for $7 \mathrm{~min}$.

\section{Electrophoresis of $P C R$ products}

The PCR products obtained were detected by agarose gel electrophoresis. An aliquot $(3 \mu \mathrm{L})$ of $5 \times$ loading dye (0.25\% bromophenol blue, $0.25 \%$ xylene cyanol FF and $13 \%$ Ficoll in water) was added to the $10 \mu \mathrm{L}$ of the PCR product, and $6 \mu \mathrm{L}$ of the mixture was loaded onto a 1.5\% agarose gel pre-stained with ethidium bromide. TBE $(0.5 \mathrm{X})$ was used as running buffer, and DNA ladder (markers) was loaded for fragment sizing. Electrophoresis was conducted at $1500 \mathrm{~V}$ for $3 \mathrm{~h}$, and the gels were viewed under ultraviolet rays.

\section{Gel extraction, DNA sequencing}

The resulting DNA fragments generated from amplifications were purified by excising bands from the agarose gel after electrophoresis. The DNA was recovered using QIAquick gel extraction kit (Qiagen). The nucleotide sequences of the purified dioscorin genes were obtained with a genetic analyser. The sequencing amplifications were performed in a $20-\mu \mathrm{L}$ reaction mixture consisting of $400 \mathrm{ng}$ of DNA to be sequenced, 10 pmole of dioscorin-specific primers $5^{\prime}$ CТССТСТССТСССТССТСТT-3' (forward primer) and 10 pmole of 5' - GGGGGTACAATGGAGAAGTG-3' (reverse primer) and $4 \mu \mathrm{L}$ of Reaction Dye Terminator Premix (Qiagen) with standard sequencing conditions. Amplification was performed in a thermowell microtitre plate (Costa Corporation) using Perkin Elmer programmable Thermal Controller model 9600 . The cycling program was 36 cycles of $94{ }^{\circ} \mathrm{C}$ for $1 \mathrm{~min}$ for denaturation, $60^{\circ} \mathrm{C}$ for $1 \mathrm{~min}$ for annealing of primers and $72{ }^{\circ} \mathrm{C}$ for 2 min for extension. Amplification products were stored at $4{ }^{\circ} \mathrm{C}$ before use. One microlitre of $125 \mathrm{mM}$ EDTA, $1 \mu \mathrm{L} 3 \mathrm{M}$ sodium acetate (pH 4.8), $25 \mu \mathrm{L} 100 \%$ ethanol $\left(-20^{\circ} \mathrm{C}\right)$ and $50 \mu \mathrm{L} 70 \%$ ethanol $\left(-20^{\circ} \mathrm{C}\right)$ were added to the amplification products, mixed and centrifuged for $10 \mathrm{~min}$ at $10,000 \mathrm{rpm}$ at $4{ }^{\circ} \mathrm{C}$. DNA pellet was dried at room temperature and re-suspended in $5 \mu \mathrm{L}$ sterile deionized distilled water. One microlitre of the re-suspended DNA was added to $9 \mu \mathrm{L} \mathrm{Hi}$ formamide, mixed and denatured for $3 \mathrm{~min}$ at $94{ }^{\circ} \mathrm{C}$. It was placed inside ABI PRISM $3130 \mathrm{X} 1$ genetic analyser, which carried out the automated sequencing analysis using a standard sequencing module with Performance Optimized Polymer and $50-\mathrm{cm}$ array.

\section{Sequence analysis}

The nucleotide sequences of the purified dioscorin genes were subsequently translated to protein sequence using bioinformatic resource tool from CLC Genomics Workbench software (CLC Bio Denmark). The nucleotide and translated protein sequences were further subjected to computer-based homology search with NCBI BLAST program. Phylogenetic analysis was carried out to compare the relationship of the major storage protein of D. bulbifera with the storage proteins of other Dioscorea spp.

\section{Results}

\section{Crude extracts}

The protein concentration of crude extracts of the aerial tuber of Dioscorea bulbifera extracted at different temperature and varying $\mathrm{pH}$ is as shown in Fig. 1. The result showed that maximum protein concentration was obtained at $\mathrm{pH} 8.3$ and at room temperature, $25^{\circ} \mathrm{C}$. 


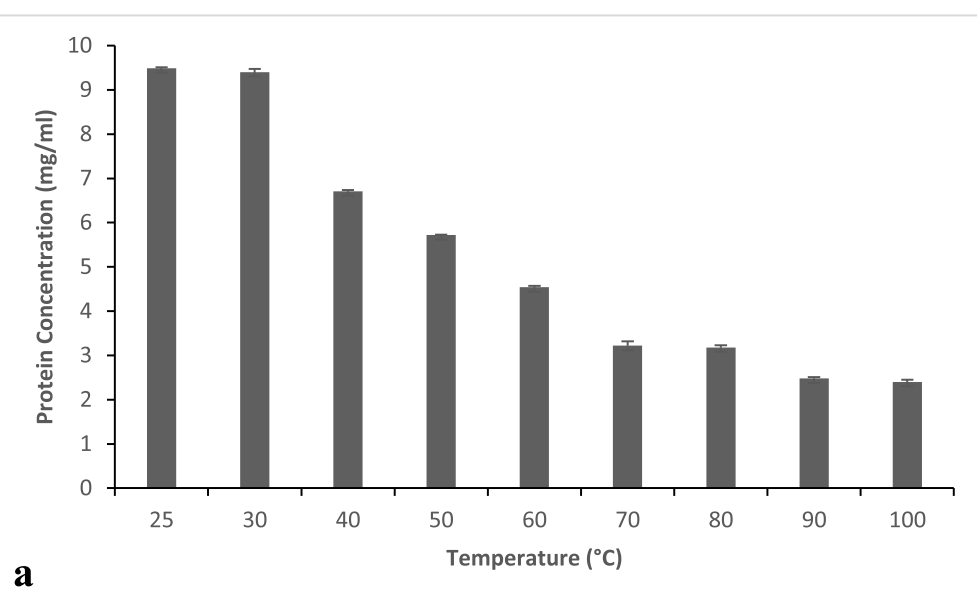

$\mathbf{a}$

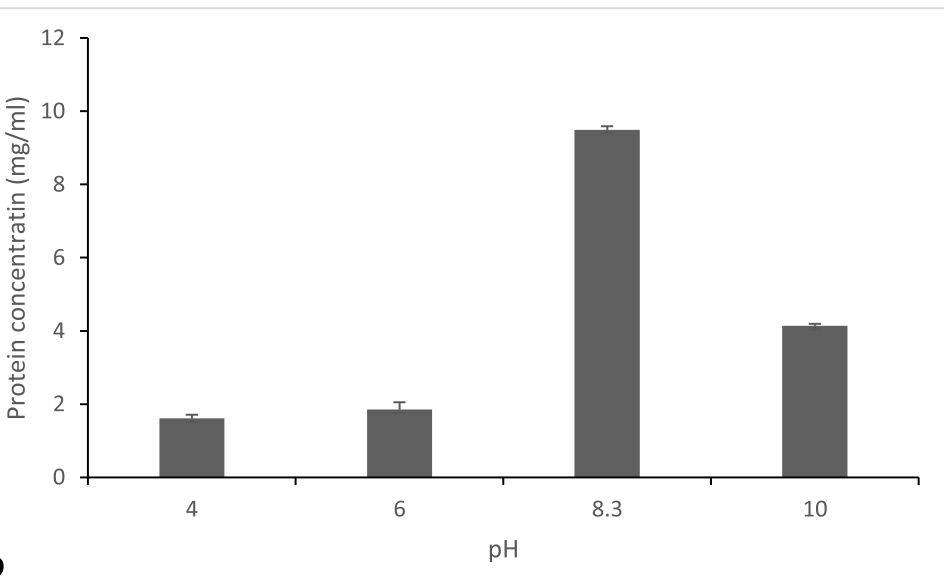

Fig. 1 Protein concentration of the crude extracts of Dioscorea bulbifera $\mathbf{a}$ at different temperature and $\mathbf{b}$ at different $\mathrm{pH}$

\section{Purification of storage protein}

The crude extract of the aerial tuber of Dioscorea bulbifera (379.60 mg) when subjected to $70 \%$ ammonium sulphate precipitation gave $130.80 \mathrm{mg}$ protein which corresponds to $34.46 \%$ yield. The elution profile of the ion-exchange chromatography on DEAE-Sepahdex A-25 of the dialyzed protein sample is as presented in Fig. 2a. Two protein peaks were obtained from the DEAE-Sephadex A- 25 column, one unadsorbed peak and the adsorbed protein peak which was eluted with $150 \mathrm{mM} \mathrm{NaCl}$. The adsorbed peak which was pooled and further purified by gel filtration on Sephadex G-75 column is as shown in Fig. 2b. At the end of purification, the amount of protein recovered was $13.20 \mathrm{mg}$, corresponding to $3.48 \%$ of the starting material.

\section{Molecular weight of $D$. bulbifera storage protein}

The molecular weight of the native storage protein of the aerial tuber of $D$. bulbifera as determined by gel filtration on Bio-gel P-100 was 22,000 Da. The subunit molecular weight, which was determined by SDS-PAGE under denaturing conditions, was estimated to be 21,095 Da (Fig. 3).

\section{Detection of protein-bound carbohydrate}

The storage protein of the aerial tuber did not stain purplish-red with Schiff's reagent suggesting that it has no covalently linked carbohydrate molecule and thus is not a glycoprotein.

\section{Amino acid composition}

The amino acid composition of the storage protein of the aerial tuber of D. bulbifera is presented in Table 1 . The amino acid composition is characterized by an abundance of neutral and charged polar amino acids, especially tyrosine, arginine, glutamate and cysteine, which constituted about $58 \%$ of the total concentration amino acids of the protein (g/100 g protein). Among the nonpolar amino acids, proline and phenylalanine were present in relatively high concentration. Of the sulphurcontaining amino acids, concentration of cysteine was higher when compared with methionine. Tryptophan, which was probably destroyed during acid hydrolysis of the protein, was not detected. 

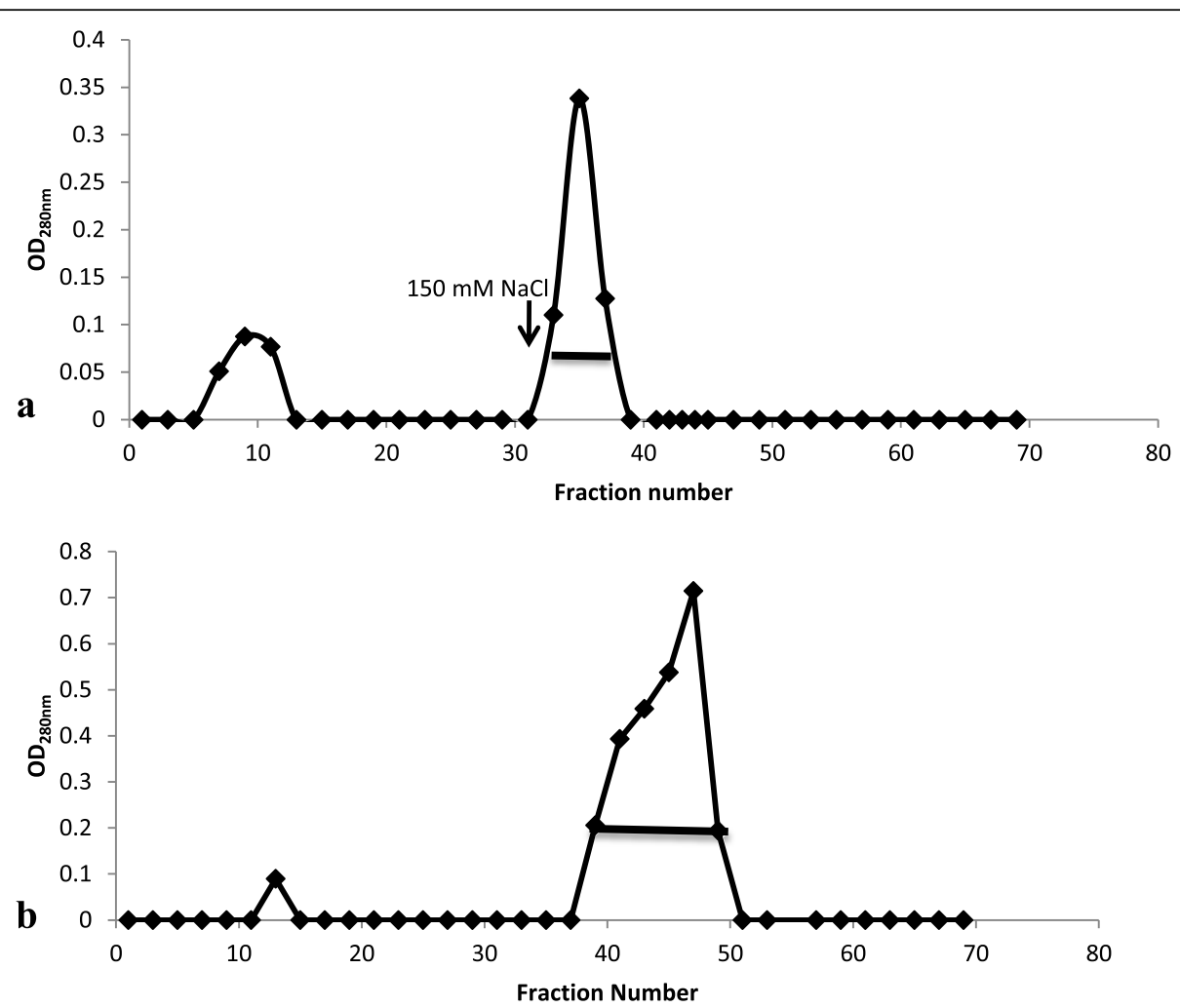

Fig. 2 Column chromatography profile of Dioscorea bulbifera. a lon-exchange chromatography of dialyzed 70\% ammonium sulphate precipitate of the extract of the aerial tuber of Dioscorea bulbifera on DEAE Sephadex A-25 column (elution buffer: $0.05 \mathrm{M} \mathrm{Tris-HCl} \mathrm{buffer} \mathrm{pH} \mathrm{8.3.} \mathrm{Adsorbed}$ protein was eluted with $0.05 \mathrm{M}$ Tris- $\mathrm{HCl}$ buffer $\mathrm{pH} 8.3$, containing $150 \mathrm{mM} \mathrm{NaCl})$. Column size $(1.5 \times 20) \mathrm{cm}$; flow rate $15 \mathrm{ml} / \mathrm{h}$; fraction size $5 \mathrm{ml}$. b Gel filtration of adsorbed peak from ion-exchange on Sephadex G-75 column (elution buffer: $100 \mathrm{mM}$ Tris-HCl pH 7.9 with $100 \mathrm{mM} \mathrm{NaCl}$ ). Column size $(1.5 \times 40) \mathrm{cm}$; flow rate $27 \mathrm{ml} / \mathrm{h}$; fraction size $3.6 \mathrm{ml}$

\section{Carbonic anhydrase activity}

The protein had low carbonic anhydrase activity $(0.202$ units/mg) as compared with standard carbonic anhydrase from bovine erythrocytes.

\section{Dehydroascorbate reductase activity}

The storage protein of the aerial tuber of $D$. bulbifera exhibited dehydroascorbate reductase activity. The protein was able to regenerate ascorbate from dehydroascorbate in the presence and absence of glutathione as shown in Fig. 4a, b. In the presence of glutathione, the specific activities of dehydroascorbate reductase for the protein were 4.14 and $6.01 \mu \mathrm{mol}$ ascorbic acid produced/ $\mathrm{min} / \mathrm{mg}$ protein at $\mathrm{pH} 6.5$ and $\mathrm{pH} 7.0$, respectively. In the absence of glutathione, the specific activities were 2.07 and $2.76 \mu \mathrm{mol}$ ascorbic acid produced $/ \mathrm{min} / \mathrm{mg}$ protein at pH 6.5 and pH 7.0, respectively. No activity was observed at $\mathrm{pH}$ 6.0.

\section{Monodehydroascorbate reductase activity}

The storage protein from the aerial tuber of $D$. bulbifera showed monodehydroascorbate reductase activity. The protein reduced monodehydroascorbate to ascorbate coupled with NADH oxidation. At pH 6.0, the activity was 0.0017 units $/ \mathrm{mg}$ which implies that the amount of protein required to oxidize $1 \mu \mathrm{mol}$ of $\mathrm{NADH}$ per min at $\mathrm{pH} 6.0$ was 0.0017 units/mg. At $\mathrm{pH} 6.5$ and $\mathrm{pH} 7.0$, the activity was 0.00038 units $/ \mathrm{mg}$ and 0.00051 units $/ \mathrm{mg}$ respectively. Monodehydroascorbate reductase activity was higher at pH 6.0 than at other pH as shown in Fig. 4c.

\section{Trypsin inhibitory activity}

Different amounts of the protein were used to determine trypsin inhibitory activity, and the activity was expressed as micrograms of trypsin inhibited as shown in Fig. 5. A positive correlation $\left(r^{2}=0.9752\right)$ was found between trypsin inhibitory activity and amounts of storage protein from the aerial tuber of $D$. bulbifera. The storage protein of the aerial tuber of $D$. bulbifera exhibited low trypsin inhibitory activity with an average of $0.94 \mu \mathrm{g}$ trypsin inhibited per $100 \mu \mathrm{g}$ of the protein.

\section{Presence of dioscorin genes}

Screening of the primer sets designed for the study with the genomic DNA samples revealed some of the specific primers were able to detect the dioscorin gene in the 


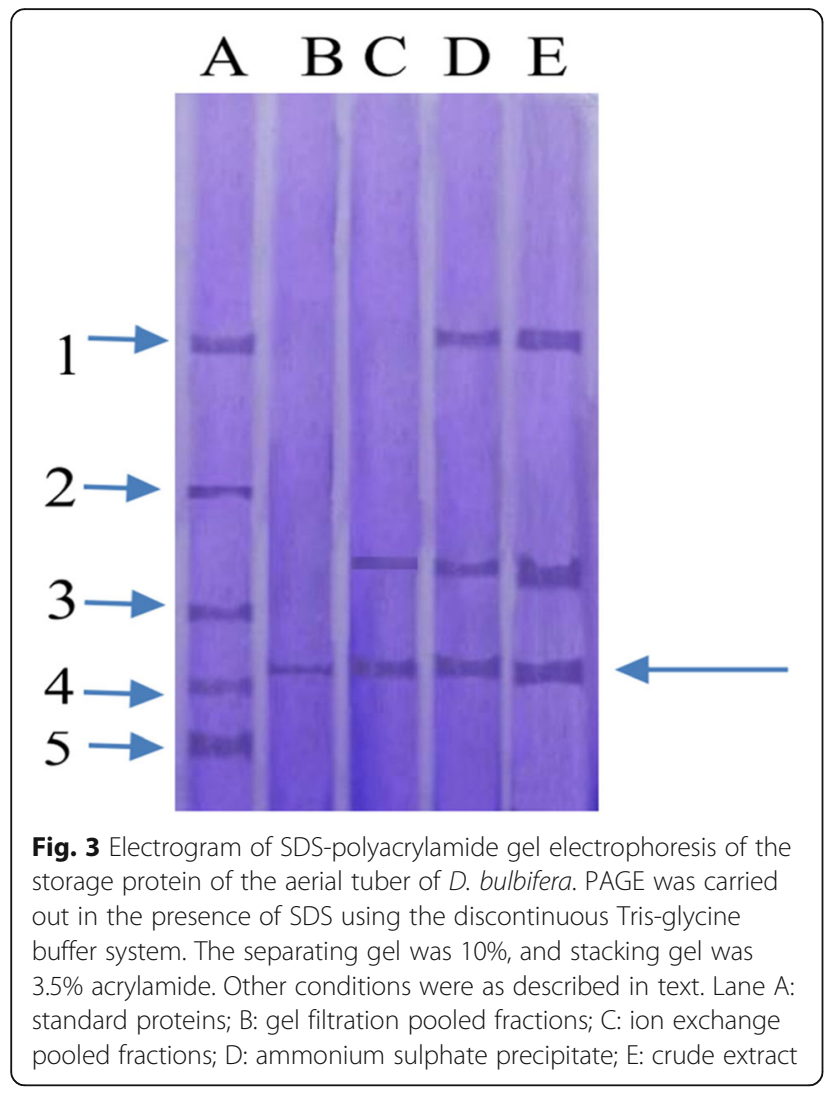

Table 1 Amino acid composition of the storage protein of Dioscorea bulbifera

\begin{tabular}{ll}
\hline Amino acid & Concentration $(\mathrm{g} / 100 \mathrm{~g}$ protein) \\
\hline Lysine & 3.50 \\
Histidine & 4.43 \\
Arginine & 11.87 \\
Aspartic acid & 4.41 \\
Threonine & 3.97 \\
Serine & 4.10 \\
Glutamic acid & 9.92 \\
Proline & 16.20 \\
Glycine & 4.39 \\
Alanine & 5.79 \\
Cysteine & 9.66 \\
Valine & 4.25 \\
Methionine & 3.75 \\
Isoleucine & 4.56 \\
Leucine & 4.09 \\
Tyrosine & 23.11 \\
Phenylalanine & 12.29 \\
Tryptophan & $\mathrm{ND}$ \\
\hline
\end{tabular}

genomic DNA sample of Dioscorea bulbifera. Target sequences are readily obtained by polymerase chain reaction if the flanking sequences of the target sequences are known. The presence of dioscorin gene was thus established in the genomic DNA extracted from the aerial tuber of Dioscorea bulbifera. Sequence analysis of dioscorin gene DNA marker produced two DNA fragments and nucleotide sequence sizes which were DBSPOOA1556 bp and DBSPOOA2-913 bp, respectively (Fig. 6a).

\section{Homologous similarities of the genes and sequence alignments}

BLAST homology search using nucleotide sequence of DBSPOOA1-556 gave significant alignments of $100 \%$ nucleotide identity with Dioscorin B from Dioscorea alata (dioB-1), 96\% nucleotide identity with Dioscorea oppositifolia microsatellite Dios23 sequence and 88\% nucleotide identity with Arabidopsis thaliana chromosome 3. DBSPOOA2-913 gave significant alignments of $91 \%$ nucleotide alignment with $D$. alata voucher GZY109 ribulose-1,5-bisphosphate carboxylase large subunit (rbcL) gene and $81 \%$ nucleotide identity with $D$. japonica voucher Hsu 231 ribulose-1,5-bisphosphate carboxylase large subunit (rbcL) gene (Table 2).

BLAST homology search using translated amino acid sequences from the nucleotide sequences of DBSPOOA1-556 and DBSPOOA2-913 also produced sequence homology with known protein sequences from Dioscorea spp. DBSPOOA1-556 conceptual amino acid sequence has $75 \%$ amino acid sequence identity with Dioscorin B from $D$. alata, $73 \%$ identity with the predicted S-type anion channel SLAH1-like from Solanum tuberosum (potato), 71\% identity with the hypothetical protein OsJ_01095 of Oryza sativa Japonica (rice) group, 68\% identity with S-type anion channel SLAH1 of $A$. thaliana and $60 \%$ amino acid sequence identity with the storage protein of Dioscorea cayenensis. The minimum molecular weight calculated from translated sequence of DBSPOOA1-556 using Protparam online server (https:// web.expasy.org/protparam/) is $20,456.38 \mathrm{Da}$, which is similar to what was obtained for the subunit molecular weight of the storage protein by SDS-PAGE $(21,095 \mathrm{Da})$. DBSPOOA2-913 conceptual amino acid sequence also showed homology with other known proteins, such as ribulose-1,5-bisphoshate carboxylase/oxygenase large subunit of $D$. bulbifera, putative carbonic anhydrase of Neosartorya fischeri and putative Dioscorin from $O$. sativa Japonica group (Table 3).

Relationship among the storage protein gene from the aerial tuber of D. bulbifera (DBSPOOA1-556 and DBSPOOA2-913) obtained in this study and the storage protein genes from other Dioscorea spp. was revealed by CLCBio homology nucleotide sequence alignment unweighted pair-group method arithmetic (UPGMA) 

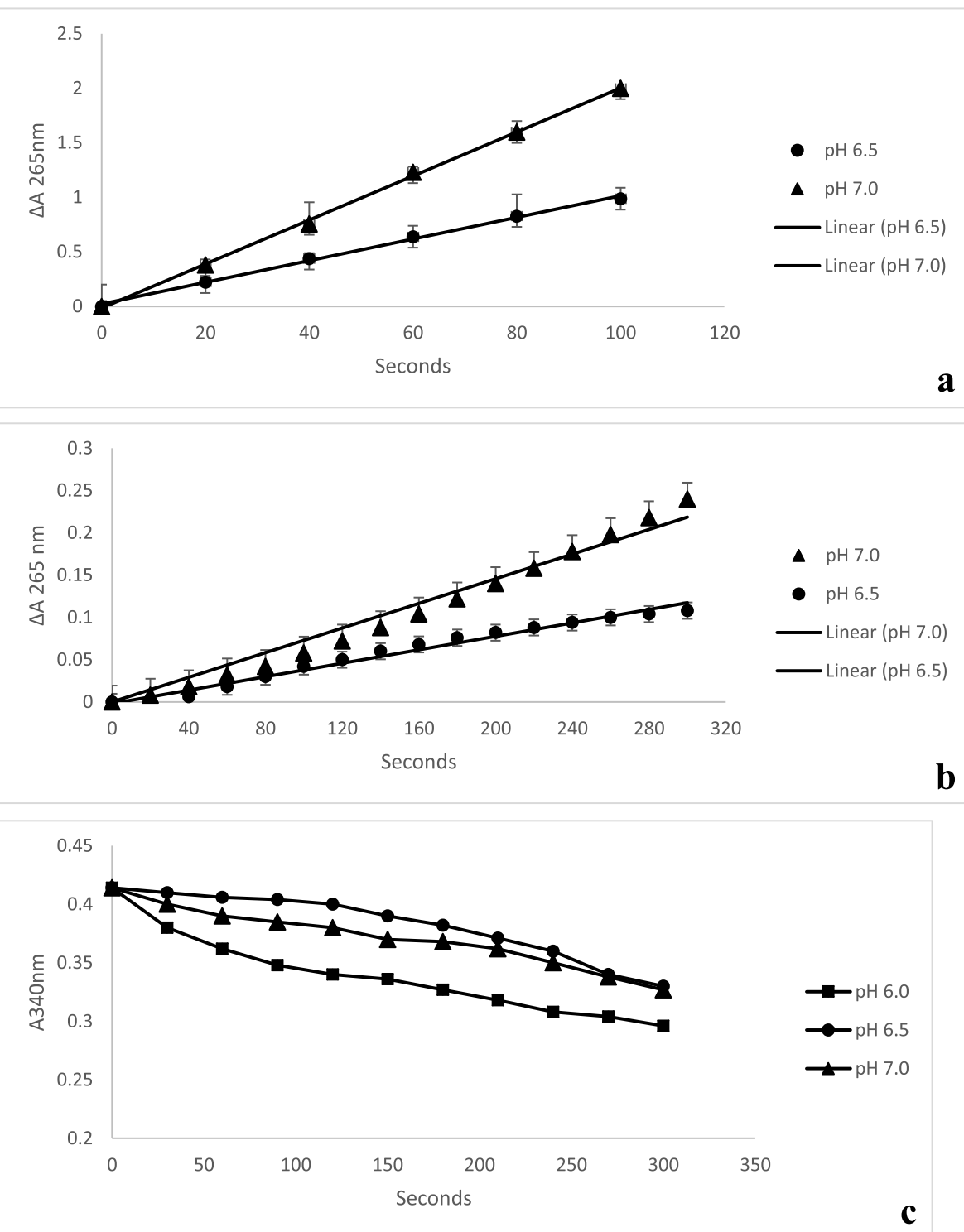

Fig. 4 Dehydroascorbate reductase activity of storage protein of the aerial tuber of D. bulbifera at pHs 6.5 and 7 with (a) or without (b) $4 \mathrm{mM}$ glutathione and (c) monodehydroascorbate reductase activity of the storage protein of the aerial tuber of D. bulbifera at pHs 6, 6.5 and 7

analysis. The analysis revealed that DBSPOOA1-556 and DBSPOOA2-913 are distinctly different. However, DBSPOOA1-556 formed a cluster with other Dioscorin genes from different Dioscorea spp. from Asian countries, but DBSPOOA2-913 was distinctly different from all known Dioscorin genes as shown in Fig. 6b.

\section{Discussion}

The crude extracts of fresh aerial tuber of $D$. bulbifera prepared at $25^{\circ} \mathrm{C}$ and at $\mathrm{pH} 8.3$ showed optimum protein concentration, which is similar to the results obtained from previous reports $[23,24]$ on the effect of heating temperature and $\mathrm{pH}$ on the major storage protein of various yam species. There was reduction in protein concentration of Dioscorea alata L. var. purpurea at increasing temperature, and at temperature above $90^{\circ} \mathrm{C}$, there was complete denaturation of the protein. Protein concentrations of $D$. alata L. var. Tainung No. 2 and D. japonica Thunb. Var. pseudojaponica showed similar trend with $D$. alata L. var. purpurea with increasing heating temperatures except that the storage proteins were not extractable at temperatures above $80^{\circ} \mathrm{C}$. Protein concentrations of the yam storage proteins were not changed after heating at temperatures between 30 and $40^{\circ} \mathrm{C}$ [23]. Protein concentration of $D$. bulbifera storage protein was highest at $\mathrm{pH} 8.3$ which compares reasonably with what was obtained for the major storage proteins of other yam tubers [18, 24-26]. 


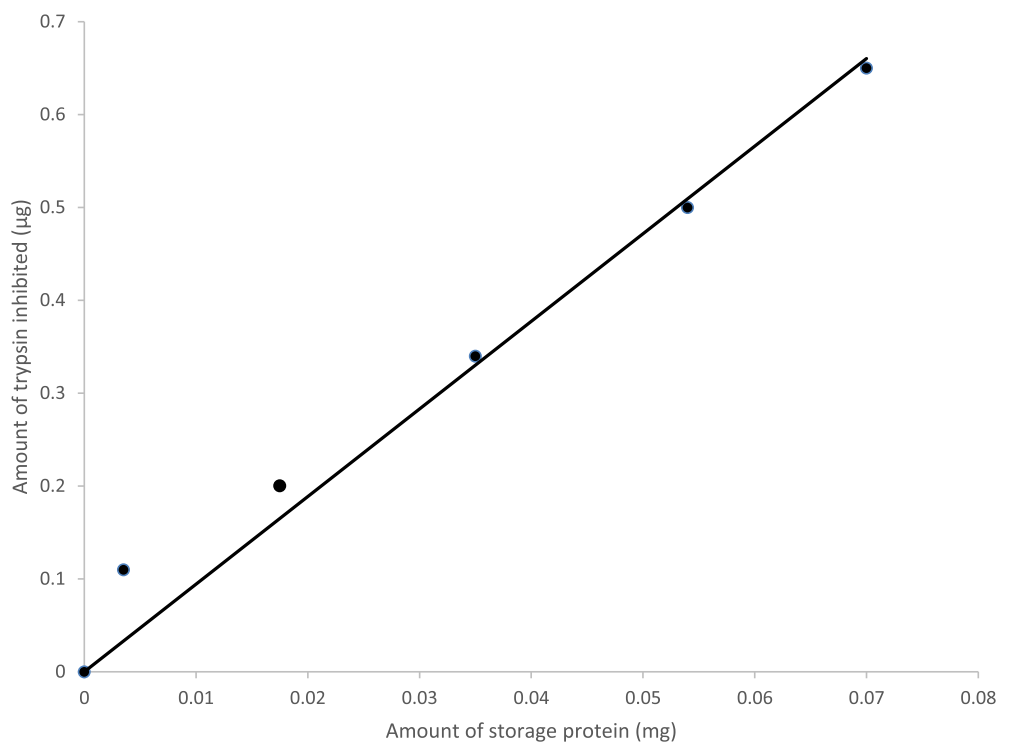

Fig. 5 Trypsin inhibitory activity of the major storage protein of the aerial tuber of D. bulbifera

At acidic medium, low protein concentrations were observed for D. alata L. var. purpurea, D. alata L. var. Tainung No. 2 and D. japonica Thunb. Var. pseudojaponica [24].

The major storage protein of the aerial tuber of D. bulbifera obtained was about $87 \%$ of the total protein of the aerial tuber which is similar to the percentage concentration of the major storage proteins from other yam tubers [27]. DB2, the major storage protein of Dioscorea batatas, accounted for $50 \%$ of the total protein of the tuber [21]. The methods of purification of the storage proteins follow similar trends of ammonium sulphate precipitation followed by ion-exchange chromatography and hydrophobic or gel filtration chromatography, or a combination of any two of these steps [21, 23]. However, some researchers purified the major storage proteins from the yam tubers using a one-step purification protocol either by ion exchange (most especially on DE-52 column) or gel filtration on Sephadex G-75 [28, 29].

The native molecular weight of $D$. bulbifera major storage protein was estimated to be $22,000 \mathrm{Da}$ while the subunit molecular weight was $21,000 \mathrm{Da}$, suggestive of a monomeric structure for the protein. This result is in contrast with those obtained for other underground yam tuber storage proteins. Dioscorins purified from other yam tubers showed a number of isoforms of about 31, 000 and $32,000 \mathrm{Da}[11,30]$. The storage protein isolated from the tuber mucilage of $D$. batatas had molecular weight above $250,000 \mathrm{Da}$ while that from $D$. cayenensis was $31,000 \mathrm{Da}$ [29]. The dioscorins isolated from $D$. batatas showed two bands $(28,000$ and $82,000 \mathrm{Da})$ on non-reducing SDS-PAGE and only one band $(32,000$ Da) under reducing condition [25]. On the other hand,
D. alata was reported to have four subunits with molecular weight of 32,000 $\mathrm{Da}$ [31], while the storage protein of Dioscorea opposita was a monomeric protein with molecular weight of 32,000 Da [32]. Wang et al. [33] also purified a 32,000-Da storage protein from $D$. purpurea. Different yam cultivars have therefore been reported to behave differently in protein composition and structure [34].

D. bulbifera storage protein is not glycosylated as shown by periodic acid Schiff's reagent (PAS) staining technique. Storage proteins from D. batatas and Dioscorea rotundata were also reported not to be glycosylated with PAS staining method [21]. On the contrary, the yam storage proteins from $D$. batatas, $D$. alata $\mathrm{cv}$. Tainong No. 1 [27] and D. japonica [22] were reported to be glycosylated using conA-peroxidase staining method. The protein from D. opposita was also shown to be glycosylated with PAS staining [32].

Amino acid composition analysis of D. bulbifera storage protein revealed that it is characterized by high content of tyrosine, proline, phenylalanine, cysteine, glutamic acid and arginine. The high content of cysteine residues showed some similarity with the dioscorins from $D$. batatas and D. japonica [22, 25, 34] with high half-cystine content. In contrast, dioscorins from four cultivars of D. alata (Tainung No. 1, Tainung No. 2, Dasan and Chanhon) had only trace amounts of cysteine [35]. Cysteine, a sulphur-containing amino acid, even though non-essential is required in the diet to meet the body's requirement. Sulphur is an important element necessary for normal growth and metabolism. Cysteine has been implicated in anti-ageing, promoting healthy hair and skin and also boosts the immune system. Cysteine 

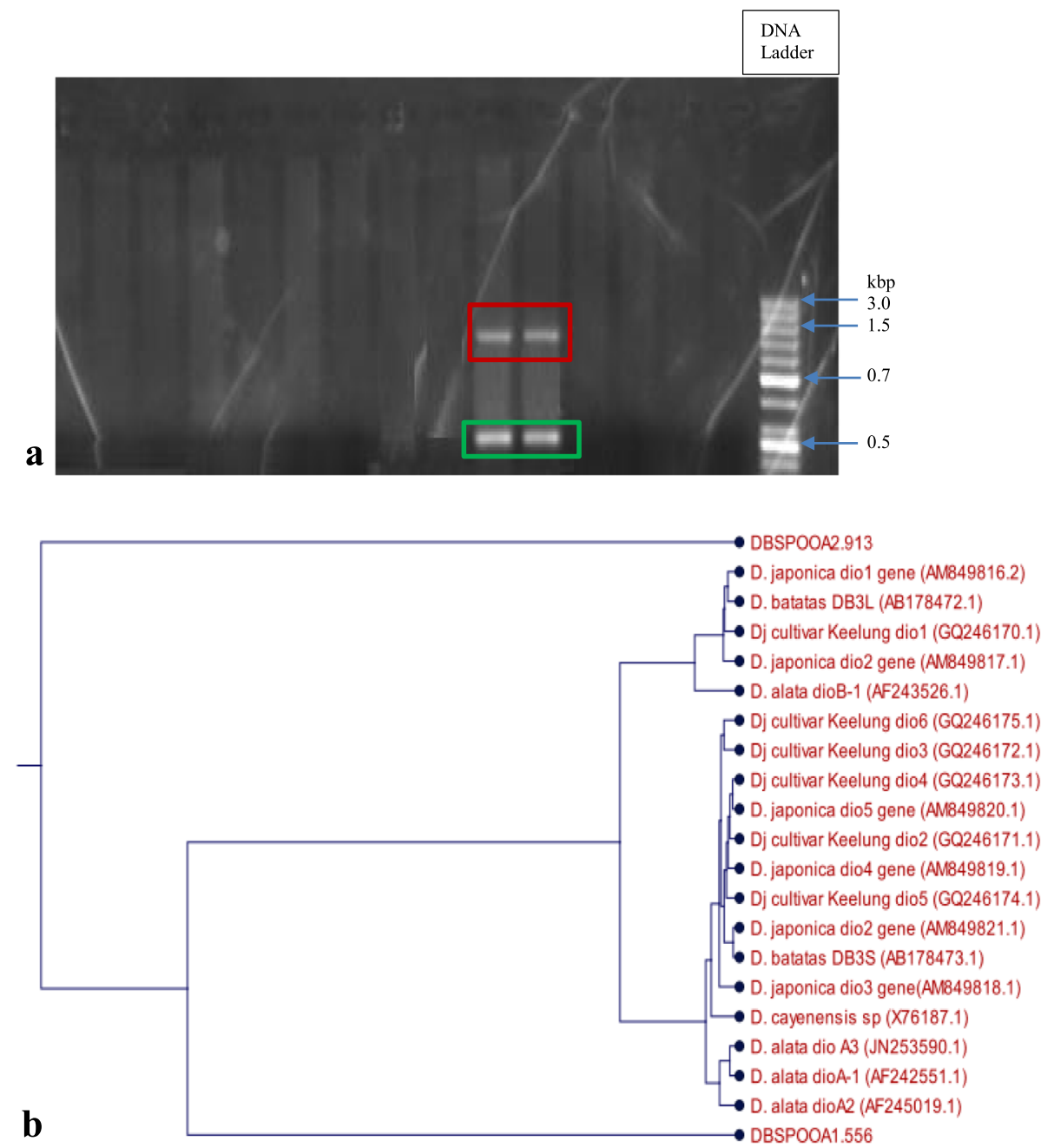

Fig. 6 a PCR amplification of D. bulbifera Dioscorin genes (DBSPOOA) with Dioscorin specific primer set (5'-CTCCTCTCCTCCCTCCTCTT-3' and 5'GGGGGTACAATGGAGAAGTG-3'). PCR products were resolved on agarose gels and stained with ethidium bromide. The last lane shows DNA ladder containing DNA fragments of defined length for sizing the bands in the experimental PCRs. The bands outlined in green and red represent DBSPOOA1 and DBSPOOA2, respectively. $\mathbf{b}$ Phylogenetic relationship between DBSPOOA genes and other Dioscorin genes

residues are also very important especially in crosslinking proteins, increasing the rigidity of proteins and also conferring proteolytic resistance. The storage protein of D. bulbifera contains high amounts of essential amino acids, approximately $40.9 \%$ of the total concentration of amino acids ( $\mathrm{g} / 100 \mathrm{~g}$ protein), especially phenylalanine and arginine.

The $22 \mathrm{kDa}$ storage protein of the aerial tuber of $D$. bulbifera exhibited carbonic anhydrase activity, albeit low. Carbonic anhydrases are zinc metalloenzymes that catalyze the simple interconversion of $\mathrm{CO}_{2}$ and $\mathrm{HCO}_{3}{ }^{-}$. They are $\mathrm{pH}$ regulatory and metabolic enzymes found in almost all organisms. In higher plants, carbonic anhydrases play a vital role in $\mathrm{CO}_{2}$ fixation during photosynthesis [36]. In mammals, they are involved in respiration [37]. Carbonic anhydrases are found in many tissue where they participate in many biological processes such as acid-base regulation, respiration, carbon dioxide and ion transport, bone resorption, ureagenesis, gluconeogenesis, lipogenesis and electrolyte secretion. Thus, they are important therapeutic targets for treatments of derangements such as edema, glaucoma, obesity, cancer and epilepsy [38]. Six genetically distinct carbonic anhydrases gene families have been identified $\left(\alpha-, \beta-, \gamma_{-}^{-} \delta_{-}, z_{-}^{-}\right.$ and $\eta$-carbonic anhydrases) [39, 40]. Hou et al. [25] showed that the major storage protein of $D$. batatas had carbonic anhydrase activity, which could not be detected in another study by Gaidamashvili et al. [21]. The discrepancies in the two reports, albeit, in the same yam species could not be explained. Also, carbonic anhydrase activity was detected in the major yam storage proteins from different species of Dioscorea, D. alata (var. Tainong 1, var. Tainong 2, var. Zhongguochang) and $D$. pseudojaponica var. Keelung [27]. Xue et al. [41] also 
Table 2 Dioscorin gene DNA marker (DBSPOOA1-556) nucleotide sequence and deduced amino acid sequence alignments and homologous details DBSPOOA1 gene

Nucleotide sequence (556 bp)

Translated amino acids sequence (184 amino acids)

Nucleotide sequence alignments

Translated amino acids sequence alignments

\begin{abstract}
CCTCTCTCTCACTCAACTITTGCCGCATCCCCCCACCACTCCCCTCCCAGCACTCCCTCTCCTCTCCTTGCCCCCC TTCTACCCTCCTGCCCCCCCGTTCCAAAACTTCTTCTATTCCCCATCTGTTITIACCAAAGATGATGATCCTTAACT TCTTCTTCCTCCACTTCTCCATTGTACCCCCTTAATTTTACGGCCAGTGGTTCACCAAAGGAAGAAAATTCTTATT GGTCGCCGCAAATCCGACGAGCTTGTTGAGCGTCATAGCCAATCTTGCCGGAGCAAGAGCTGCG GCAAGAATGGGATGGAAAGAGAGTGCGGTTTGCATGTTITCACTAGCCATGACTCATTACCTCGTGTTATTCGTA ACCTTGTATCAGCGTCTACAAGGCAGCAACAGCCTTCCGGCGATGCTCCGTCCGGCTITCTTCCTCTTCTTCGCCG CACCGAGCATGGCCAGTTTCACCTGGGTGTCAATTTCCGGCGAATTCGACATCTCATGCAAAATGCTITCTTCCTT TCTCTTTTCCTCTTCACTTCTCCATTGTACCCCCT
\end{abstract}

\section{SLSLNFCRIPPPLPSQHSLSSPCPPSTLLPPRSKTSSIPHLFLPKMMILNFFFLHFSIVPPFYGQWFTKGRKFLLVAANPT SLLSVIANLAGARAAARMGWKESAVCMFSLAMTHYLVLFVTLYQRLQGSNSLPAMLRPAFFLFFAAPSMASFTWVS ISGEFDISCKMLFFLSLFLFTSPLYP}

1. Dioscorea alata Dioscorin B (dioB-1) mRNA, complete cds; 100\% identity; Accession (AF243526.1) 2. Dioscorea oppositifolia microsatellite Dios 23 sequence; 96\% identity; Accession (JQ955632.1)

3. Dioscorea cirrhosa isolate PS5034MT03 ribulose-1,5-bisphosphate carboxylase/oxygenase (rbcL) gene, partial cds; chloroplast; 95\% identity; Accession (HQ637837.1)

4. Dioscorea alata voucher GZY110 ribulose-1,5-bisphosphate carboxylase/oxygenase large subunit (rbcL) gene, partial cds; chloroplast; 95\% identity; Accession (JX139768.1)

5. Ipomoea batatas voucher GZY116 ribulose-1,5-bisphosphate carboxylase/oxygenase large subunit (rbcL) gene, partial cds; chloroplast; 95\% identity; Accession (JX139773.1)

6. Arabidopsis thaliana chromosome 3, complete sequence; 88\% identity; Accession (CP002686.1)

1. Dioscorin B [Dioscorea alata]; 75\% identity; Accession (AAF44711.1)

2. PREDICTED: S-type anion channel SLAH1-like [Solanum tuberosum]; 73 \% identity; Accession (XP 006342228.1)

3. Hypothetical protein OsJ_01095 [Oryza sativa Japonica Group]; 71\% identity; Accession (EAZ11241.1)

4. S-type anion channel SLAH1 [Arabidopsis thaliana]; 68\% identity; Accession (NP_176418.2)

5. Storage protein [Dioscorea cayenensis]; 60\% identity; Accession (CAA53781.1) revealed that yam storage proteins, dioscorins, catalyse reactions assumed by carbonic anhydrases.

Ascorbic acid (vitamin C) is a plant secondary metabolite involved in a number of physiological processes. The main role of ascorbic acid is to neutralize free radicals and prevent against oxidative damage [42]. It also functions as a cell signalling modulator in cell division, growth regulation and senescence in plants $[43,44]$. Because of the deleterious effects of reactive oxygen species (mostly as a result of salt imbalance), plants usually have well-developed enzymatic and non-enzymatic antioxidant defense system [45]. In plants, enzymes involved in the ascorbate-glutathione pathway (ascorbic acid-specific peroxidase, monodehydroascorbate reductase, dehydroascorbate reductase and glutathione reductase) assist in peroxides (formed as by-products of normal metabolism or as a result of environmental stresses) detoxification [46]. In its role as an antioxidant, ascorbic acid is univalently oxidized to monodehydroascorbate, an endogenous index of oxidative stress, which in turn rapidly dissociates to form ascorbic acid and dehydroascorbate in a reaction catalysed by mondehydroascorbate reductase [46]. Thus, monodehydroascorbate reductase and dehydroascorbate reductase are important in the regulating ascorbic acid level and its redox state during oxidative stress [47]. The major storage protein of the aerial tuber of $D$. bulbifera was shown to have both dehydroascorbate reductase and monodehydroascorbate reductase activities. The dehydroascorbate reductase activity was higher in the presence of gluthathione. Dehydroascorbate reductase activity was also detected without gluthatione but was lower when compared to the activity in the presence of gluthathione. The activity was also found to be $\mathrm{pH}$ dependent. At $\mathrm{pH} 6.0$, there was no activity detected without gluthatione. This is similar to the report of the yam storage proteins, dioscorins, of $D$. batatas tuber which displayed both dehydroascorbate reductase and monodehydroascorbate reductase activities with and without gluthathione [18]. These activities might represent an important defense in the cytoplasm of yam cells in response to environmental oxidative stress [18].

Most storage proteins have been reported to play protective roles against environmental stresses, such as acting as protease inhibitors [48]. Protease inhibitors in plants are usually termed as anti-nutritional compounds because of their ability to inhibit digestive enzymes. However, their presence in plants is often as a result of an evolutionary adaptation which allows plants to survive under natural conditions [49]. In plants, protease inhibitors may be important in regulating and controlling endogenous proteinases, serving as storage proteins, and acting as protective agents against insect and microbial proteases. Protease inhibitors have also been classified under potential cancer-protective micro-components, by controlling misfunctioning of certain proteases in cancer progression [49]. The N-terminal amino acid sequences 
Table 3 Dioscorin gene DNA marker (DBSPOOA2-913) nucleotide sequence and deduced amino acid sequence alignments and homologous details DBSPOOA2 gene

Nucleotide sequence (913 bp)

Translated amino acid sequence (304 amino acids)

Nucleotide sequence alignments

Translated amino acid sequences alignments

\begin{abstract}
ACCCTCATGGGTGTCGGTGAGGAGAAGGTGACCCGGCAGCGGAGTTTTTCGCAGGAGATAGAGGAGTCCAGGGAGA CCTACGGTGGGCTGTTATGAATGTCTACGTGGGGGACTTGATITACCAAAGATGATGACGCTGATGAAGGGGGGGAA AAGCACGGGAGGGTGAGTCATGGCTGGTGAAAACTTGCTAACCGCACTCTCTITCCATCCCATTCTGGCCGCAGCT CTTGCTCCGGCAAGATTGGCTATGACGCTCAACAAGCTCGGCGGATTTGCGGCGACCAATAAGAATTTCTTCCTTG GGGAACCACTGGTCGTAGATTITTACGTCGAGGACAATTACCGGGAGCGAAAAGAAGAGACACACAAGAATGAAC GGAGGAGATTGAGGATCAAGAAAAGGAGTTGATTGGAGAAGGAGCAAGAAAGAATTCCAAGGTGCGAATAGATAGT TCATGCCGATATAGTCAGACAACTCGGCGCGAACATGGTGGAACTGGCGGAGGCACCGGAGGAGGAAGAGGAGGG AGGAGAGGAGAACTATTTCTCTGCTTTACCTCCAATTATCATCTAATGTGATTCCCTCCTTCCATAAAATCCATCTTATCT TTATTAAAATGGGTGCTCTTCTACCTGCTGCTAATATTCCATAAACCACTTGATAACCTGAATTTATTIATCTITATCCTA CTGTACAAGGCATCTTAGAAAAAGCGTTGTTCCTTCTTTCTACCACATCCAACTTGGATTGTTATTCCCTTCCTTTGCA AAATTTATATAAGATTITITTCCTCTCGAATAACCCTGTGACCCCTTIAGCTGGGTGAACTITCACCATTCGGACAT GCTCTCCTGTACCATATTITCTITGTGCCTGCTTCCTATTTACCCCTCCCACAA
\end{abstract}

TLMGVGEEKVTRQRSLFAGDRGVQGDLRWAVYECLRGGLDFTKDDDADEGGEKHGRVSHGWKLANRTLFPSHSGRSS CSGKIGYDAQQARRICGDQEFSSFGEPLWDFYVEDNYRERKEETHKNERRRLRIKKRSLEKEQERIPRCEIVHADIVRQL GANMVELAEAPEEEEEGGEENYFSALPPIIICDSLLPNPSYLYNGCSSTCCYSINHLITIYLSLSYCTRHLRKSWSFFLPHPT WIVIPFLCKIYIRFFFPLEPCDPFSWVNFSPFGHALLYHIFLCACFLFTPPT

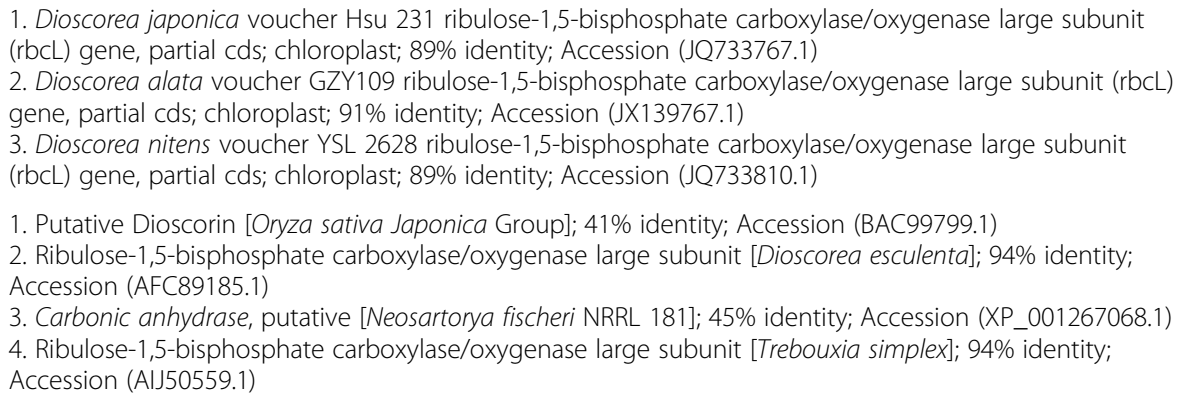

1. Dioscorea japonica voucher Hsu 231 ribulose-1,5-bisphosphate carboxylase/oxygenase large subunit (rbcL) gene, partial cds; chloroplast; 89\% identity; Accession (JQ733767.1)

2. Dioscorea alata voucher GZY109 ribulose-1,5-bisphosphate carboxylase/oxygenase large subunit (rbcL) gene, partial cds; chloroplast; 91\% identity; Accession (JX139767.1)

3. Dioscorea nitens voucher YSL 2628 ribulose-1,5-bisphosphate carboxylase/oxygenase large subunit (rbcL) gene, partial cds; chloroplast; 89\% identity; Accession (JQ733810.1)

1. Putative Dioscorin [Oryza sativa Japonica Group]; 41\% identity; Accession (BAC99799.1)

2. Ribulose-1,5-bisphosphate carboxylase/oxygenase large subunit [Dioscorea esculenta]; 94\% identity; Accession (AFC89185.1)

3. Carbonic anhydrase, putative [Neosartorya fischeri NRRL 181]; 45\% identity; Accession (XP_001267068.1)

4. Ribulose-1,5-bisphosphate carboxylase/oxygenase large subunit [Trebouxia simplex]; 94\% identity; Accession (AlJ50559.1)

of storage proteins purified from yam bean (Pachyrhizus erosus), YGB1 and YGB2, showed high homology to cysteine protease, but both of them exhibited low protease activities using azocasein as substrates [50]. The storage protein from the aerial tuber of D. bulbifera had low trypsin inhibitory activity as compared with those from sweet potato roots [48]. However, just like the result obtained from this study, dioscorin from $D$. batatas showed only a weak trypsin inhibitory activity, with $1.9 \mu \mathrm{g}$ of trypsin inhibited per $100 \mu \mathrm{g}$ of the protein [25]. Large amounts of these storage proteins could provide a significant protective role in the aerial tuber even with this low trypsin inhibitory activity.

Two dioscorin gene DNA markers were amplified from the total genomic DNA of the aerial tuber of $D$. bulbifera, DBSPOOA1-556 and DBSPOOA2-913 using primers designed with NCBI primer BLAST tool and Primer 3. In a study done by Barman et al. [51], dioscorin gene was also amplified from RNA extracted from different species and cultivars of Dioscorea using forward and reverse primers designed with NCBI primer BLAST tool and Primer 3 software. The deduced amino acid sequences from $D$. bulbifera genes gave sequences of 184 and 304 amino acid residues respectively. The deduced amino acid sequences from DBSP00A1-556 was highly homologous to the amino acid sequences from the storage proteins of $D$. alata (dio-B) (75\% identity) and $D$. cayenensis (60\% identity). The deduced amino acid sequences for the two genes did not show any similarities with tuber storage protein genes of patatin and sporamin. Proteins of the same family normally perform the same biochemical function and may be related phylogenetically [52]. Amino acid sequence analyses have been found necessary for unambiguous evidence of structural relationship among proteins. Proteins with structural similarities tend to have evolutionary and functional similarities. In addition to having sequence similarities with the storage proteins from $D$. cayenensis and $D$. alata (dio-B), the translated amino acid sequence from DBSPOOA1-556 had homologous sequences with the predicted S-type anion channel SLAH1-like from Solanum tuberosum, and S-type anion channel SLAH1 from Arabidopsis thaliana. The predicted S-type anion channel from Solanum tuberosum is a hypothetical protein OsI_01095 from Oryza sativa Japonica group and the S-type anion channel SLAH1 (SLAC1-homolog protein 1) from Arabidopsis thaliana is a slow and weak voltage-dependent S-type anion efflux channel which is involved in the maintenance of anion homeostatis. Also, the translated amino acid sequence from DBSPOOA2924 was highly homologous with a putative dioscorin from Oryza sativa Japonica group and putative carbonic anhydrase from Neosartorya fischeri NRRL 181. Of the two genes of the storage protein from the aerial tuber of 
D. bulbifera, DBSPOOA1-556 formed a cluster with other dioscorin genes from different Dioscorea spp. from Asian countries, but DBSPOOA2-913 was distinctly different from all known dioscorin genes. This could be because it is an aerial tuber and not an underground tuber. It could also be because of the different geographical locations in which the yam species are cultivated. Several factors such as root-crop species, local climate and fertilization pattern have been reported to directly influence the composition of root crops [35]. The yam species used in this study was cultivated in Africa in contrast to various reported studies of other yam species, $D$. alata, $D$. cayenensis, and D. japonica which are cultivated in Asian countries.

\section{Conclusion}

In conclusion, a storage protein was isolated from the aerial tuber of Dioscorea bulbifera for the first time. The storage protein has similar functional properties and structural homology with the storage proteins of other Dioscorea species. The storage protein is heat stable and exhibited carbonic anhydrase, dehydroascorbate reductase and trypsin inhibitory activities. It is also a good source of essential amino acids; thus, the protein may be suitable for development as functional food.

\section{Authors' contributions}

AK designed, developed and conceptualised the study. OAA carried out all experiments, analysis and interpretation of data in this study as her PhD research project under the supervision of AK and wrote the first draft of the manuscript. Both authors read and approved the final manuscript.

\section{Funding}

This research did not receive any specific grant from funding agencies in the public, commercial, or not-for-profit sectors.

\section{Availability of data and materials}

The datasets used and/or analysed during the current study are available from the corresponding author on reasonable request.

\section{Ethics approval and consent to participate}

Not applicable

\section{Consent for publication}

Not applicable

\section{Competing interests}

The authors declare that they have no competing interest.

\section{Author details}

${ }^{1}$ Department of Chemical Sciences, Afe Babalola University, Ado Ekiti, Nigeria. ${ }^{2}$ Department of Biochemistry and Molecular Biology, Obafemi Awolowo University, lle-Ife, Nigeria.

Received: 13 November 2019 Accepted: 5 June 2020 Published online: 13 July 2020

\section{References}

1. Wong KL, Lai YM, Li KW, Lee KF, Ng TB, Cheung HP, Zhang YB, Lao L, Wong RN-S, Shaw PC (2015) A novel, stable, estradiol-stimulating, osteogenic yam protein with potential for the treatment of menopausal syndrome. Sci Rep 5:10179
2. Islam MT, Chowdhury RU, Afroz R, Rahman S, Haque MM (2011) Characterization and maintenance of yam (Dioscorea spp.) germplasm. Bangladesh J Agric Res 36(4):605-621

3. Asiedu R, Sartie A (2010) Crops that feed the world 1. Yams Food Sec 2(4): 305-315

4. Chen C-T, Wang Z-H, Hsu C-C, Lin H-H, Chen J-H (2017) Taiwanese and Japanese yam (Dioscorea spp.) extracts attenuate doxorubicin-induced cardiotoxicity in mice. J Food Drug Anal 25(4):872-880 https://doi.org/10. 1016/j.jda.2016.09.002

5. Liu S-F, Chang S-Y, Lee T-C, Chuang L-Y, Guh J-Y, Hung C-Y, Hung T-J, Hung Y-J, Chen P-Y, P-f H (2012) Dioscorea alata attenuates renal interstitial cellular fibrosis by regulating Smad-and epithelial-mesenchymal transition signaling pathways. PLoS One 7(11):e47482

6. Alinnor I, Akalezi C (2010) Proximate and mineral compositions of Dioscorea rotundata (white yam) and Colocasia esculenta (white cocoyam). Pak J Nutr 9(10):998-1001

7. Lu Y-L, Chia C-Y, Liu Y-W, Hou W-C (2012) Biological activities and applications of dioscorins, the major tuber storage proteins of yam. J Tradit Complement Med 2(1):41-46

8. Zhang Z, Gao W, Wang R, Huang L (2014) Changes in main nutrients and medicinal composition of Chinese yam (Dioscorea opposita) tubers during storage. J Food Sci Technol 51(10):2535-2543

9. Shewry PR (2017) Cereal seed storage proteins. In: Seed development and germination, Routledge, pp 45-72

10. Paredes-Lopez O (2018) Amaranth biology, chemistry, and technology: 0. CRC Press

11. Shewry PR (2003) Tuber storage proteins. Ann Bot 91(7):755-769

12. Fujiwara T, Nambara E, Yamagishi K, Goto DB, Naito S (2002) Storage proteins. The Arabidopsis Book/American Society of Plant Biologists, $p 1$

13. Galani V, Patel D (2017) A comprehensive phytopharmacological review of Dioscorea bulbifera Linn. Int J Env Sci Nat Res 4(5):177-187. https://doi.org/ 10.19080/IJESNR.2017.04.555650

14. Subasini U, Thenmozhi S, Sathyamurthy D, Vetriselvan S, Victor Rajamanickam G, Dubey G (2013) Pharmacognostic and phytochemical investigations of Dioscorea bulbifera L. Int J Pharm Life Sci 4(5)

15. Mulualem T, Mekbib F, Hussein S, Gebre E (2018) Analysis of biochemical composition of yams (Dioscorea spp.) landraces from Southwest Ethiopia. Agrotechnology 7:177

16. Maisnam D, Rasane P, Dey A, Kaur S, Sarma C (2017) Recent advances in conventional drying of foods. J Food Technol Preserv 1(1)

17. Nwadike E, Enibe S, Nwabanne J (2018) Determination of the engineering properties of aerial yam and water yam. Int J Adv Sci Res Eng 4(11):297-306

18. Hou W-C, Chen H-J, Lin Y-H (1999) Dioscorins, the major tuber storage proteins of yam (Dioscorea batatas Decne), with dehydroascorbate reductase and monodehydroascorbate reductase activities. Plant Sci 149(2): $151-156$

19. Shiu P-J, Ju Y-H, Chen H-M, Lee C-K (2013) Facile isolation of purple membrane from Halobacterium salinarum via aqueous-two-phase system. Protein Expr Purif 89(2):219-224

20. Ekeanyanwu R (2013) Evaluation of the crude protein and amino acid composition of Nigerian Monodora myristica (Ehuru). Pak J Nutr 12(3): 219-223

21. Gaidamashvili M, Ohizumi Y, lijima S, Takayama T, Ogawa T, Muramoto K (2004) Characterization of the yam tuber storage proteins from Dioscorea batatas exhibiting unique lectin activities. J Biol Chem 279(25):26028-26035

22. Xue Y-L, Miyakawa T, Sawano Y, Tanokura M (2012) Cloning of genes and enzymatic characterizations of novel dioscorin isoforms from Dioscorea japonica. Plant Sci 183:14-19

23. Chen Y-T, Lin K-W (2007) Effects of heating temperature on the total phenolic compound, antioxidative ability and the stability of dioscorin of various yam cultivars. Food Chem 101(3):955-963. https://doi.org/10.1016/j. foodchem.2006.02.045

24. Chen Y-T, Kao W-T, Lin K-W (2008) Effects of pH on the total phenolic compound, antioxidative ability and the stability of dioscorin of various yam cultivars. Food Chem 107(1):250-257. https://doi.org/10.1016/j.foodchem. 2007.08.017

25. Hou W-C, Liu J-S, Chen H-J, Chen T-E, Chang C-F, Lin Y-H (1999) Dioscorin the major tuber storage protein of yam (Dioscorea batatas Decne) with carbonic anhydrase and trypsin inhibitor activities. J Agric Food Chem 47(5): $2168-2172$ 
26. Hou W-C, Lee M-H, Chen H-J, Liang W-L, Han C-H, Liu Y-W, Lin Y-H (2001) Antioxidant activities of dioscorin, the storage protein of yam (Dioscorea batatas Decne) tuber. J Agric Food Chem 49(10):4956-4960

27. Hou W-C, Chen H-J, Lin Y-H (2000) Dioscorins from different Dioscorea species all exhibit both carbonic anhydrase and trypsin inhibitor activities. Bot Bull Acad Sinica 41(3):191-196

28. Liu Y-H, Liang H-J, Cheng H-C, Liu Y-W, Hou W-C (2006) Comparisons of in vitro antioxidant activities of storage proteins in tuber of two Dioscorea species. Bot Stud 47:231-237

29. Conlan S, Griffiths L-A, Turner M, Fido R, Tatham A, Ainsworth C, Shewry P (1998) Characterisation of the yam tuber storage protein dioscorin. J Plant Physiol 153(1):25-31. https://doi.org/10.1016/S0176-1617(98)80040-0

30. Conlan RS, Griffiths L-A, Napier JA, Shewry PR, Mantell S, Ainsworth C (1995) Isolation and characterisation of CDNA clones representing the genes encoding the major tuber storage protein (dioscorin) of yam (Dioscorea cayenensis Lam.). Plant Mol Biol 28(3):369-380. https://doi.org/10.1007/ bf00020387

31. Wanasundera J, Ravindran G (1994) Nutritional assessment of yam (Dioscorea alata) tubers. Plant Foods Hum Nutr 46(1):33-39

32. Nagai T, Nagashima T (2006) Functional properties of dioscorin, a soluble viscous protein from Japanese yam (Dioscorea opposita thunb.) tuber mucilage Tororo. Z Naturforsch C 61(11-12):792-798

33. Wang C-H, Chen M-J, Tseng C-Y, Wei K-M, Chen W (2013) Structural characterization of functional compositions isolated from Dioscorea Purpurea (Cultivar of Ming-Chien) by Raman Spectroscopy. Nat Prod Chem Res 1(3)

34. Liao Y-H, Wang C-H, Tseng C-Y, Chen H-L, Lin L-L, Chen W (2004) Compositional and conformational analysis of yam proteins by near infrared Fourier transform Raman spectroscopy. J Agric Food Chem 52(26):81908196

35. Huang C-C, Chiang P-Y, Chen Y-Y, Wang C-C (2007) Chemical compositions and enzyme activity changes occurring in yam (Dioscorea alata L.) tubers during growth. LWT Food Sci Technol 40(9):1498-1506

36. Wei-Hong S, Yan-You W, Zhen-Zhen S, Qiu-Xia W, Xin-Yu W (2014) Enzymatic characteristics of higher plant carbonic anhydrase and its role in photosynthesis. J Plant Stud 3(2):39

37. Chegwidden WR, Carter ND, Edwards YH (2013) The carbonic anhydrases: new horizons, vol 90 Birkhäuser

38. Supuran CT (2008) Carbonic anhydrases: novel therapeutic applications for inhibitors and activators. Nat Rev Drug Discov 7(2):168

39. Del Prete S, Vullo D, Fisher GM, Andrews KT, Poulsen S-A, Capasso C, Supuran CT (2014) Discovery of a new family of carbonic anhydrases in the malaria pathogen Plasmodium falciparum-The $\eta$-carbonic anhydrases. Bioorg Med Chem Lett 24(18):4389-4396

40. Supuran CT, Capasso C (2016) New light on bacterial carbonic anhydrases phylogeny based on the analysis of signal peptide sequences. J Enzyme Inhib Med Chem 31(6):1254-1260

41. Xue Y-L, Miyakawa T, Nakamura A, K-i H, Sawano Y, Tanokura M (2015) Yam tuber storage protein reduces plant oxidants using the coupled reactions as carbonic anhydrase and dehydroascorbate reductase. Mol Plant 8(7):11151118

42. El-Gendy KS, Aly NM, Mahmoud FH, Kenawy A, El-Sebae AKH (2010) The role of vitamin $C$ as antioxidant in protection of oxidative stress induced by imidacloprid. Food Chem Toxicol 48(1):215-221

43. Conklin P, Barth C (2004) Ascorbic acid, a familiar small molecule intertwined in the response of plants to ozone, pathogens, and the onset of senescence. Plant Cell Environ 27(8):959-970

44. Upadhyaya CP, Venkatesh J, Gururani MA, Asnin L, Sharma K, Ajappala H, Park SW (2011) Transgenic potato overproducing L-ascorbic acid resisted an increase in methylglyoxal under salinity stress via maintaining higher reduced glutathione level and glyoxalase enzyme activity. Biotechnol Lett 33(11):2297

45. Hasanuzzaman M, Hossain MA, Fujita M (2011) Nitric oxide modulates antioxidant defense and the methylglyoxal detoxification system and reduces salinity-induced damage of wheat seedlings. Plant Biotechnol Rep 5(4):353

46. Anjum NA, Umar S, Chan M-T (2010) Ascorbate-glutathione pathway and stress tolerance in plants. Springer Science \& Business Media

47. Hasanuzzaman M, Alam M, Rahman A, Hasanuzzaman M, Nahar K, Fujita M (2014) Exogenous proline and glycine betaine mediated upregulation of antioxidant defense and glyoxalase systems provides better protection against salt-induced oxidative stress in two rice (Oryza sativa L.) varieties. Biomed Res Int 2014

48. Hou W-C, Lin Y-H (2002) Sweet potato (Ipomoea batatas (L.) Lam) trypsin inhibitors, the major root storage proteins, inhibit one endogenous serine protease activity. Plant Sci 163(4):733-739

49. Duranti M (2006) Grain legume proteins and nutraceutical properties. Fitoterapia 77(2):67-82

50. Hou W-C, Lin Y-H (1997) Dehydroascorbate reductase and monodehydroascorbate reductase activities of trypsin inhibitors, the major sweet potato (Ipomoea batatas [L.] Lam) root storage protein. Plant Sci 128(2):151-158

51. Barman P, Choudhary AK, Geeta R (2017) A modified protocol yields highquality RNA from highly mucilaginous Dioscorea tubers. 3 Biotech 7(2):150

52. Zeldovich KB, Shakhnovich El (2008) Understanding protein evolution: from protein physics to Darwinian selection. Annu Rev Phys Chem 59:105-127

\section{Publisher's Note}

Springer Nature remains neutral with regard to jurisdictional claims in published maps and institutional affiliations.

\section{Submit your manuscript to a SpringerOpen ${ }^{\circ}$ journal and benefit from:}

- Convenient online submission

- Rigorous peer review

- Open access: articles freely available online

High visibility within the field

- Retaining the copyright to your article

Submit your next manuscript at $>$ springeropen.com 